\title{
Pharmacognostical and Phytochemical study of Sala (Shorea robusta)
}

\author{
Authors \\ Dr Santosh Kumar Gupta ${ }^{1}$, Dr Raman Ranjan², Dr Mahendra Pd. Singh ${ }^{3}$, \\ Dr D.S.Verma ${ }^{4}$ \\ ${ }^{1}$ MD (Ay), AMO, Dist. Ayu. Hosp. Raigarh \\ 9584338909, Email: sk_gupta80@yahoo.com \\ ${ }^{2} \mathrm{MD}$ (Ay), AMO, GAD, Raigarh \\ Email: raman.ranjan27@gmail.com \\ ${ }^{3}$ Asso. Prof., Dravyaguna Dept.,Govt. Ayurveda College Patna \\ ${ }^{4}$ Prof., Shalya Dept., Govt. Ayurveda College Patna
}

Pharmacognosy is the science of identification of natural drugs and their physical, botanical and chemical properties. In addition, medicinally active secondary metabolites of plants have afforded a phytochemical foundation on which the subject is now being considered. India has a long tradition of the use of drugs derived from plants in the Ayurvedic system of medicine. It has been stated that over 2000 plants grow in India which have medicinal properties in which maximum species are found in wild state and some are cultivated.

Sala (Shorea robusta) which is easily available and frequently found in several formulations with special emphasis on twak vikara to evaluate its multidimensional qualities and to assess the efficacy of resin in the management of wound. Sal as a sal tree was identified in Atharvaveda kala. It resin pacifies kaphaj roga. Krimi roga, vidradhi, skin diseases etc.

In Charak Samhita Sal is mentioned as Shal, Aswakarna, Sarja, Sarjarasa. These are the synonyms of shal. It is a constituent of Vedanasthapana mahakashaya and Udarprashmana mahakashaya. It is mentioned in Chandanadi taila in Jwara Chikitsa, Urahkshata Chikitsa, Kshatkshina Chikitsa.

Botanical Name - Shorea robusta Gaertn..

Taxonomy of Plant

Domain: Eukaryota Kingdom: Plantae

Subkingdom : Viridiplantae

Phylum: Tracheophyta Class: Magnoliopsida Order : clusiales

Family : Dipterocarpae

Botanical name : shorea robusta

Vernacular Names

Eng: sal Hindi : sala Kannada: kabba, sala Malyalam: salavriksham, mulappumartu Sanskrit: salah, aswakarnah Tamil: salam Telugu: sarjakamu , guggilamu

\section{Botanical Description}

Physical Description

Trees up to $40 \mathrm{~m}$ tall, deciduous; trunk to $2 \mathrm{~m}$ in diam.; crown spreading. Bark grey to dark reddish brown, becoming fissured and flaky; inner bark not laminated; wood hard; heartwood dark brown. 
Branchlets densely buff scabrous-pubescent. Stipules fugacious, lanceolate, small, lepidote ; petiole 2-2.5 cm, buff scabrous-pubescent. Leaf blade $10-40 \times 5-24 \mathrm{~cm}$, ovate to oblong, thinly leathery, midvein prominent abaxially and conspicuous adaxially, lateral veins ca. 12 pairs prominent abaxially, tertiary veins densely scalariform, glabrous, base obtuse to cordate, apex acuminate. Flowers subsessile, on panicles to25 $\mathrm{cm}$; branches racemose, secund; bracts caducous, minute. Petals strongly contorted, creamy-yellow or sometimes with a medium pink stripe, $1-1.5 \mathrm{~cm}$ $\times$ ca. $5 \mathrm{~mm}$, linear. Sepals ovate, to $2 \mathrm{~mm}$ in bud, subequal, densely buff pubescent. Stamens many; anthers panduriform, setose toward apex; connective appendages short, stout, exceeding anther apex, sparsely setose. Ovary ovoid, densely buff pubescent. Fruit sepals unequal, spatulate, sparsely pubescent, 3 longer to $8 \times 1.5 \mathrm{~cm}, 2$ smaller to $3.5 \times 0.5 \mathrm{~cm}$; nut ovoid, ca. $5 \times 12 \mathrm{~mm}$. Fl. Feb-May, fr. May-Jul.

A large sub-deciduous tree, seldom quite leafless, found extensively in parts of North-east and central India. Bark reddish brown or grey, smooth or longitudinally fissured, leaves $10-30 \mathrm{~cm}$, ovateoblong, coriaceous, shining when mature; flowers in lax, axillary or terminal panicles, yellowish, small; fruit $10-15 \mathrm{~mm}$ long, $10 \mathrm{~mm}$ in diameter, ovoid, reddish to pale yellowish green in colour, indehiscent, one seeded with five, somewhat unequal, 5-7 cm long, wing like persistent sepals; seed ovoid, with fleshy unequal cotyledons.

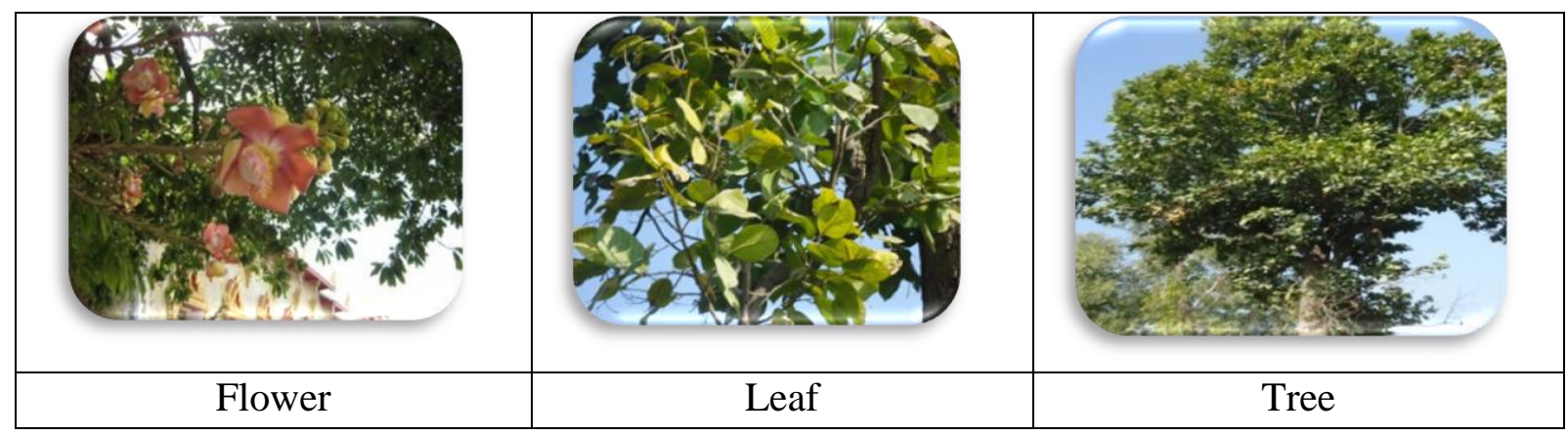

\section{Distribution}

Sal has two main regions of distribution, one on the north and the other on the south of Gangetic plain. The extreme north western limit of the northern region is in the Kangra district of Himachal Pradesh and extends along the sub Himalayan tract and outer Himalayas as far east as the Darrang district in Assam to Tripura. To the south of Ganges, sal is distributed from western parts of West Bengal through Orissa up to Vishakhapatnam in the south and through greater part of eastern and southern M.P. up to Chhindwara and Hoshangabad districts in the west.

\section{Climate and Soil}

The region in which sala is found vary widely as regards to climate. In valleys of western sub Himalayan tract as well as in parts of central India, the tree suffers considerably from frost. In Eastern part of northern region of distribution it thrives in moist but equable climate and its range in Assam is limited mainly by humidity which induces undergrowth, resulting in soil conditions unfavourable for establishment of sal seedlings.

The absolute max. temperature varies from about 44 at high elevations to about $47 \mathrm{c}$ in hottest parts of Bihar and the absolute min under $-1 \mathrm{C}$ to $7 \mathrm{C}$; annual rainfall $1100 \mathrm{~cm}$ to $450 \mathrm{~cm}$. The most favorable soil for growth of sala is well drained, moist deep sandy loam, with good sub soil drainage. It therefore thrives well on the deep boulder deposits overlain by a sufficient depth of fertile porous loam, as flanking the outer Himalayas. An excesss of clay in the sob soil produces stunted growth. In the central Indian or Peninsular region it occurs as variety of geological formations of which chief are griess, mica, schist, quartzite, sandstone.

Under average conditions sal attains a height of 18 $-30 \mathrm{~m}$ and a girth of $1.8-2.1 \mathrm{~m}$, though under 
very favourable conditions, trees up to $45 \mathrm{~m}$ in height and $3.6 \mathrm{~m}$ or more in girth have been recorded. Under unfavourable conditions and in poor quality of forests the trees become stunted and have a height of $9-12 \mathrm{~m}$ and a girth of $0.9-$ $1.2 \mathrm{~m}$. Trees growing under favourable conditions in forests have a clean and straight bore, varying in length under different conditions of growth; 18 $-24 \mathrm{~m}$ long clear bole has been recorded in $45 \mathrm{~m}$ tall trees.

Parts Used - bark, resin

\section{Actions and Uses -}

The bark \& leaves are astringent, acrid, cooling, anthelmintic, alexeritic, anodyne, constipating, urinary astringent, union promoter, depurative They are useful in vitiated conditions of kapha and pitta, ulcers, wounds, otalgia, bacterial infections, diarrhoea, dysentery, gonorrhoea, leucorrhoea, pruritis, leprosy, cough, haemorrhoids, anaemia.

Fruits are sweet, astringent, cooling, aphrodisiac, cholagogue, and tonics are useful in dipsesis, burning sensation, tubercular ulcers, and seminal weakness.

Resin is sweet, acrid, cooling, anodyne, vulnerary, antibacterial, deodorant, constipating, detergent, carminative, stomachic, aphrodisiac, expectorant, ophthalmic and tonic. It is useful in vitiated conditions of pitta, wounds, ulcers, neuralgia, burns, pruritis, fractures, fever, diarrhoea, dysentery, haemorrhoids, gonorrhoea, menorragia, splenomegaly, obesity, cephalagia, odontalgia, burning of eyes, and opthalmodynia.

\section{Ayurvedic Properties -}

Rasa - Kashaya (Dhanwantari Nighantu), Kashaya (Bhava Prakash Nighantu), Katu, tikta (Raja Nighantu) katu,Tikta, tuvara, madhura (Nighantu Ratnakara)
Guna - Ruksha (Dhanwantari Nighantu), Usna, snigdha (Raj Nighantu), Ruksha, snigdha (Nighantu Ratnakar)

Veerya - Sheeta (Raj Nighantu), Usna, sheeta (Nighantu Ratnakar)

Karma - Doshaj - Kaphapaha ( Dhanwantari Nighantu), Kapha pitta hara( Madanpal Nighantu), Kaphahara (Bhava Prakash), Sleshmahara (Saligram Nighantu), Vatakara, pittanasaka (Nighantu Ratnakara)

Dhatuj - Raktadosha hara (Nighantu Ratnakar)

\section{Macroscopic-}

Thick, protuberated, transverse cracks and fine longitudinal striation, greyish brown, outer surface rough, inner surface fibrous, fibres longitudinal and oblique, oblique cracks prominent, inner surface brown in colour.

Microscopic study of Powder- Powder greyish brown in colour and microscopically examination shows fragments of cork cells, stone cells, parenchyma cells with starch grains, thick walled fibre patches of adjacent cells of fibres with prismatic crystals of calcium oxalate, medullary rays with interlocking arrangements.

\section{Identity, Purity\& Strength}

$\begin{array}{ll}\begin{array}{l}\text { Moisture content (w/w \%) } \\ \text { Ash Values (w/w \%) }\end{array} & 4.5 \% \\ \text { a) Total Ash } & 10.6 \% \\ \text { b) Acid Insoluble Ash } & 3.55 \% \\ \text { c) Sulphated Ash } & 15.6 \% \\ \text { Extractive Values (\% w/w) } & \\ \text { a) Water Soluble Extractives } & 13.45 \% \\ \text { b) Alcohol Soluble Extractives } & 16.23 \% \\ \text { Volatile Content } & 2.5 \%\end{array}$

\section{Chemical test qualitative-}

Tannin, Resines, Essential oil, Terpenoid: +ve

Therapeutic Use - Pittakaphashamaka

Formulations - Sarjaparpati, Ayaskriti, Salsaradi kvatha, Sarjarasadi malahara, Atasyadi lepa, Panchaguna taila, Chandanadya taila. Dose - Gum resin -1 to $3 \mathrm{gm}$, bark \& Wood decoction -50 to $100 \mathrm{ml}$, Flower powder -3 to $5 \mathrm{gm}$. 


\section{JMSCR Vol||05||Issue||09||Page 28021-28029||September}

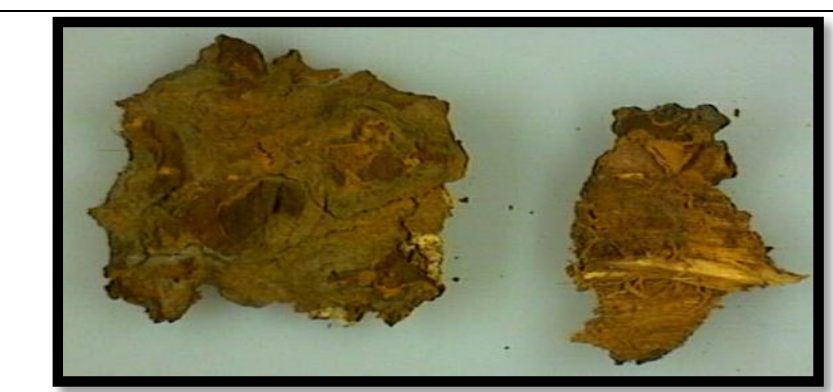

Shala bark

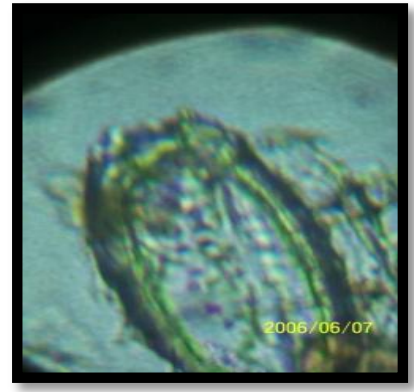

Stone cell with content Cell with content and starch grains

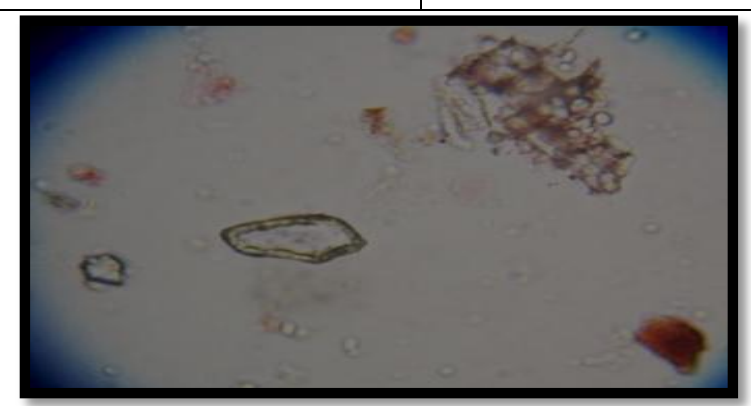

Stone cell with content and starch grains

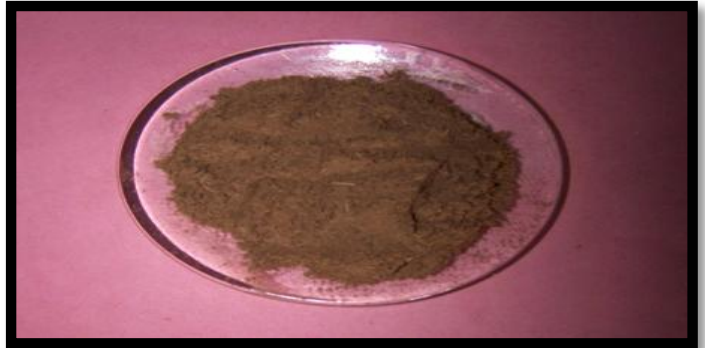

shala bark powder

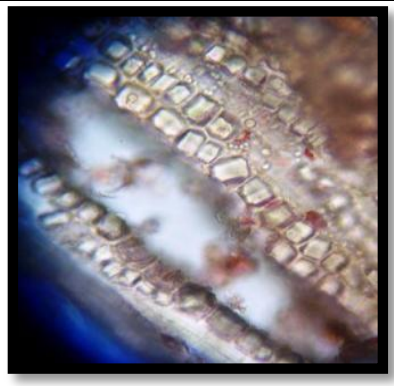

Cells with calcium Calcium oxalate prismatic oxalate crystals crystals and cell with prismatic crystals

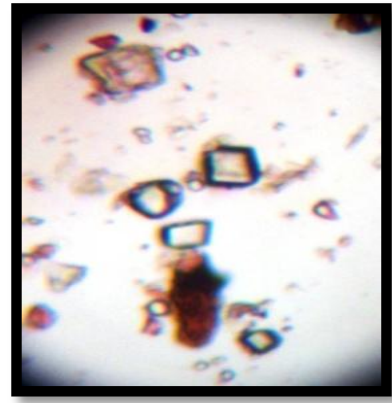

content.

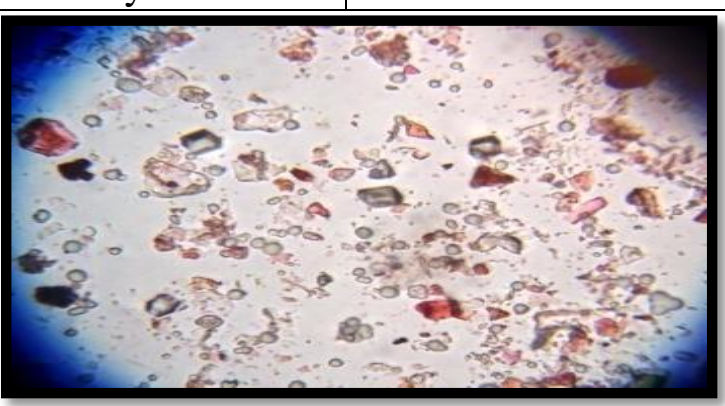

Calcium oxalate prismatic, starch grains and cell with content

\section{Fluorescence Study -}

\begin{tabular}{|c|c|c|c|}
\hline S.NO. & Treatment & Under ordinary light & Under UV - Long (366nm) \\
\hline 1. & Drug as such & Brown & Brown \\
\hline 2. & Drug + Nitrocellulose & Dark brown & Blackish brown \\
\hline 3. & Drug + Picric acid & Yellowish brown & Brown \\
\hline 4. & Drug $+\mathrm{HCl}_{\text {conc. }}$ & Blackish brown & Yellowish brown \\
\hline 5. & Drug $+\mathrm{H}_{2} \mathrm{SO}_{4 \text { conc. }}$ & Reddish brown & Black \\
\hline 6. & Drug $+\mathrm{HNO}_{3(50 \%)}$ & Dark brown & Yellowish brown \\
\hline 7. & Drug $+1 \mathrm{~N} \mathrm{Na} \mathrm{OH}$ in $\mathrm{Me} \mathrm{OH}$ & Black & Black \\
\hline 8. & Drug + $1 \mathrm{~N} \mathrm{Na} \mathrm{OH}$ in Water & Blackish brown & Brown \\
\hline 9. & Drug $+\mathrm{NH}_{4} \mathrm{OH}$ & Dark grey & Grey \\
\hline 10. & Drug $+\mathrm{FeCl}_{3}$ & Blackish grey & Grey \\
\hline 11. & Drug + Acetic acid ${ }_{\text {Glacial }}$ & Blackish brown & Yellowish grey \\
\hline 12. & Drug + Sudan-III & Reddish brown & Reddish Grey \\
\hline
\end{tabular}

[Chase \& Pratt, 1949.,Kokaski, et al.,1958) with some modification] 
TLC of alcoholic extract TLC of Sala Bark

\section{Visualized in UV}

\begin{tabular}{|l|c|}
\hline Stationary phase & TLC Aluminium sheet silica gel 60 F 254 plate \\
\hline Mobile phase & Toluene - Ethyl Acetate - Methanol - Acetic acid ( $7: 3: 1: 0.3)$ \\
\hline Rf value of spots Visualized in UV 254 nm & $0.15,0.20,0.25,0.30,0.35 \& 0.55$ \\
\hline Rf value of spots Visualized in UV 366 nm & $0.20,0.30,0.45,0.50,0.55$ (Light green), $0.60 \& 0.70$ \\
\hline
\end{tabular}

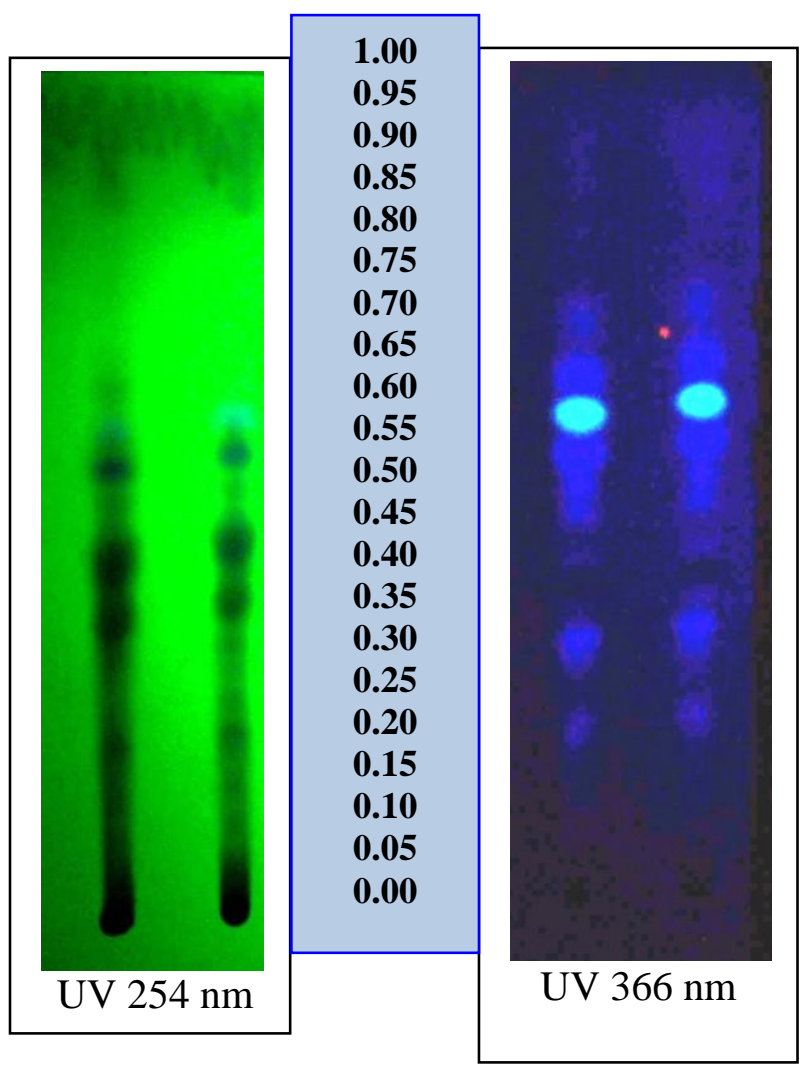

\section{Visualized after spray}

\begin{tabular}{|l|c|}
\hline Stationary phase & TLC Aluminium sheet silica gel 60 F 254 plate \\
\hline Mobile phase & Toluene - Ethyl Acetate - Methanol - Acetic acid (7:3: 1:0.3) \\
\hline $\begin{array}{l}\text { Rf value of spots Visualized after spray of sulphuric acid } \\
\text { reagent and heated 110C for 5 minutes }\end{array}$ & $0.15,0.20,0.40,0.45,0.50$ \& 0.55 \\
\hline
\end{tabular}

\section{TLC of Sala bark}

\section{TLC of Sala bark}

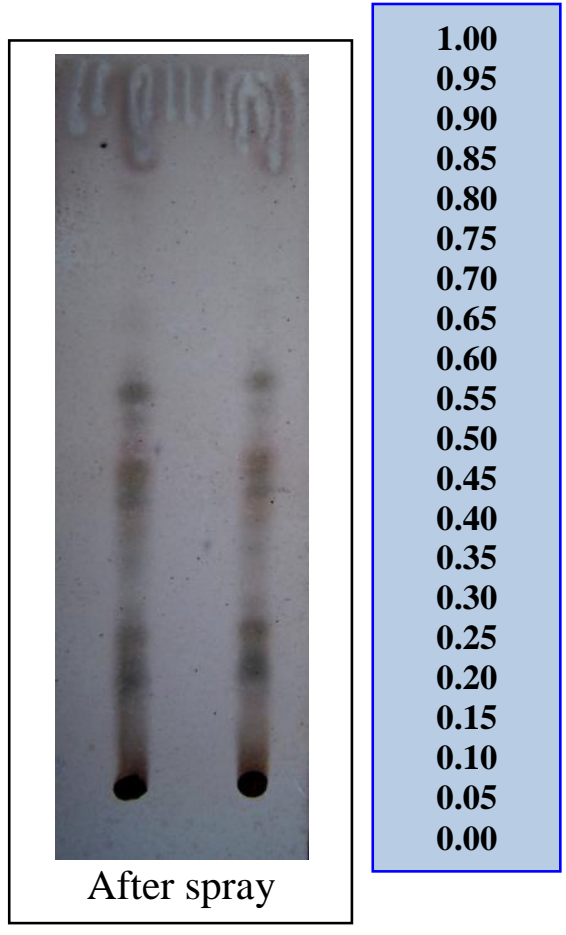


Sala (Ral-Resin) - (Shorea robusta Roxb. Ex Gaertn.f.)

Sala-Rala consists of dried creamish white resin of Shorea robusta Roxb. ex Gaertn.f. (Fam. Dipterocarpaceae), a large sub - deciduous tree, found in deciduous forests $13.3 \%$ throughout the India, covering part of North, East and Central India up to an altitude $900-1700 \mathrm{~m}$.

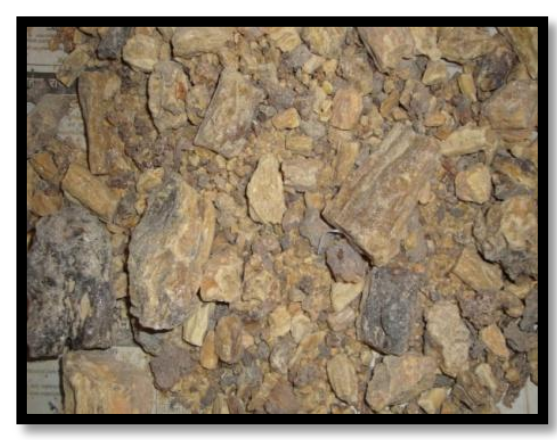

Resin of Sala

Microscopic view of resin of sala
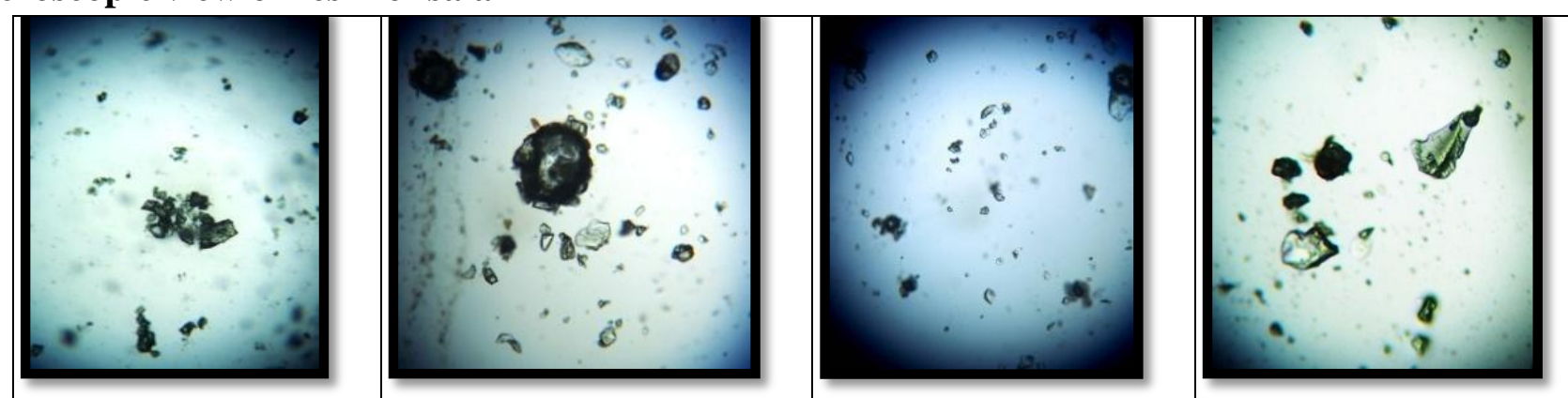

Different types of crystalline mass and crystal like particles in microscopy

Very few yellowish oil globules and numerous, small or large, rhomboidal crystalline fragments present in group or single.

\section{Identity, Purity\& Strength}

Moisture content (w/w \%) $1.25 \%$

Ash Values (w/w \%)
a) Total Ash
$3.85 \%$
b) Acid Insoluble Ash
$2.55 \%$
c) Sulphated Ash
$5.45 \%$
Extractive Values (\% w/w)
a) Water Soluble Extractives $\quad 4.5 \%$
b) Alcohol Soluble Extractives $43.8 \%$

Therapeutic Use - Pittakaphashamaka

Formulations - Sarjarasadi malahara, Atasyadi lepa, Panchaguna taila, Chandanadya taila.

Dose - Gum resin - 1 to $3 \mathrm{gm}$.

\section{Fluorescence Study}

[Chase \& Pratt, 1949., Kokaski, et al.,1958) with some modification]

\section{Description}

Macroscopic- Drug occurs in vermicular or stalactites pieces of creamish white coloured mass, makes $40 \%$ emulsion in hot water and 50 to $70 \%$ soluble in alcohol and readily burns with white flame and aromatic smell; odour, aromatic, taste., bitter and astringent.

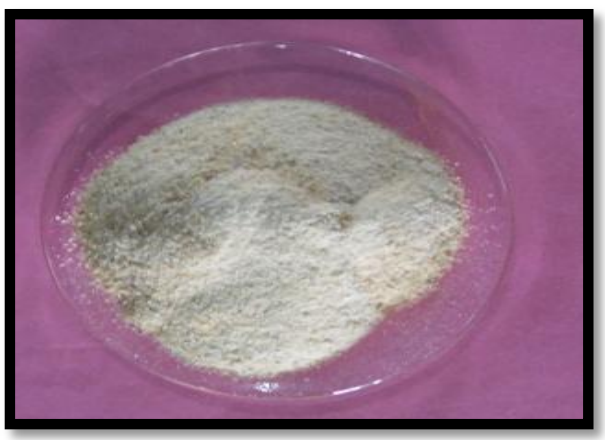

Ral Powder 
TLC of alcoholic extract TLC of Sala Ral

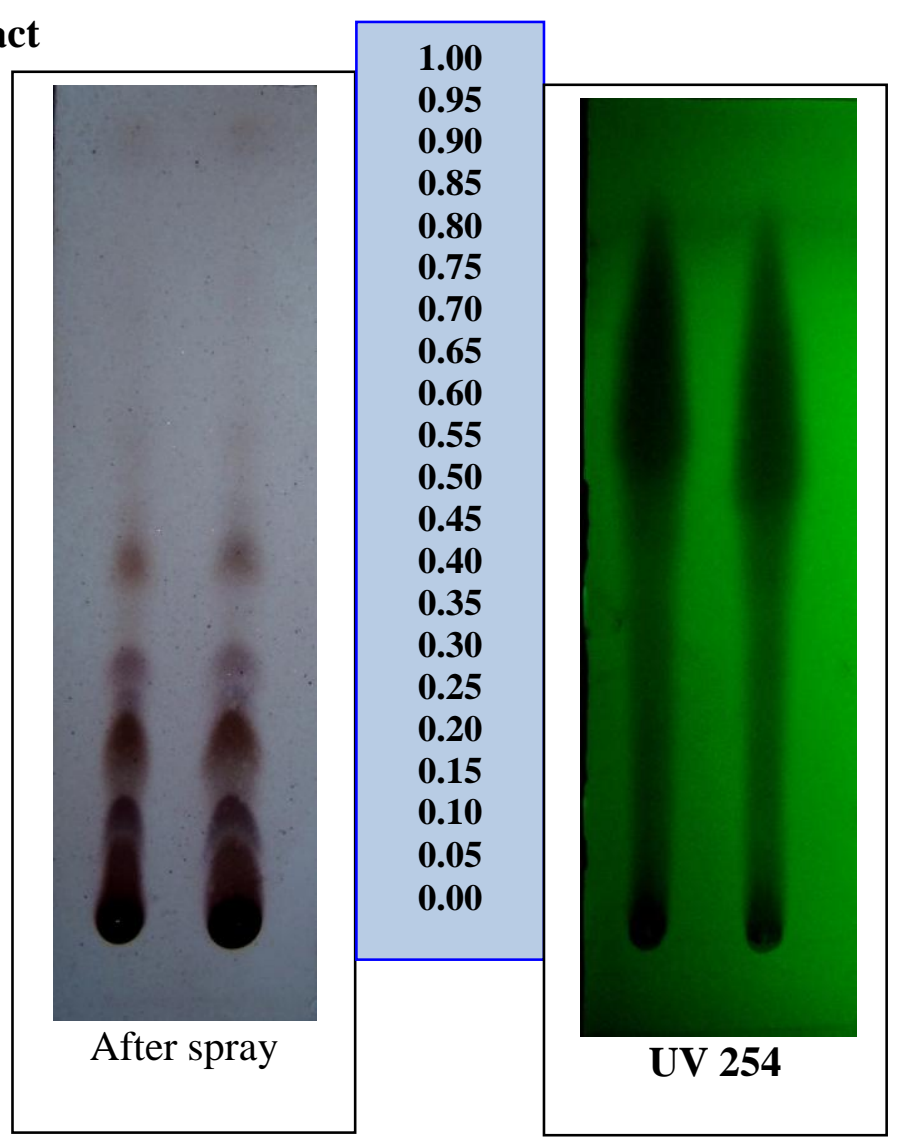

\section{Visualized after spraying Sulphuric acid reagent}

\begin{tabular}{|l|l|}
\hline Stationary phase & TLC Aluminium sheet silica gel 60 F 254 plate \\
\hline Mobile phase & Hexane - Chloroform - Methanol (15: 15: 15) \\
\hline $\begin{array}{l}\text { Rf value of spots Visualized after spray of sulphuric } \\
\text { acid reagent and heated 1100C for 5 minuts }\end{array}$ & $0.05,0.10,0.20,0.25,0.30,0.43 \& 0.90$ \\
\hline
\end{tabular}

\section{Visualized in UV 254}

\begin{tabular}{|l|l|}
\hline Stationary phase & TLC Aluminium sheet silica gel 60 F 254 plate \\
\hline Mobile phase & Chloroform - Methanol (14: 2) \\
\hline $\begin{array}{l}\text { Rf value of spots Visualized after spray of sulphuric } \\
\text { acid reagent and heated 1100C for 5 min. }\end{array}$ & $0.45 \& 0.55$ \\
\hline
\end{tabular}

\section{Chemical Analysis}

The destructive distillation of $100 \mathrm{~g}$ of dry sal wood gave the following: charcoal -37.20 , acetic acid -2.5 , formic acid -0.27 , methyl alcohol 0.76 and soluble tar $-4.91 \mathrm{~g}$, settled tar -4.31 , and pyrogenous liquor $-28.55 \mathrm{cc}$, and gas -12.55 litres. Analysis of wood gave water - 12.5, alphacellulose - 44.04, lignin - 32.44, pentosans 17.50, ash $-0.53 \%$. Heartwood of Shorea robustayeilded hopeaphenol, leucoanthocyanidin $[(+) 5,7,3$ '4'tetrahydroxy flavan $-3,4$-diol $]$, two triterpinoids ( C30H48O5.H2O, m.p., 90 - 92), a terpene alcohol (m.p., $156-58$ ) and some waxy impurities [paerson \&brown,1, 112; Trotter, 1944,161,214; Indian woods. 1, 147; Unasylva,
1953,7,30; Quereshi, Indian For. 1968, 94,51; Krishna \& Ramaswami, Indian For.Bull, N.S. No.79, 1932,23; Madhav.et.al Phytochemistry, 1967,6,1155].

Bark - Huge quantities of bark of sal are available during conversion of logs. In larger logs2.7-3.0 m in girth, the output may be about 38 percent. Sal bark along with leaves and twigs is a promising tanning material. The tannin content of the various parts is as follows: bark, 7-12; young leaves, 20; twigs and leaves, 22; and powder dust, $12 \%$. The spray dried aqueous extract of the bark contains 39.6 percent of tannins with a tans/non-tans ratio of 0.73 . 
The extract is of a pale reddish colour and the tannins are of pyrogallol type. The extract may be used locally for cheap tanning or in blend with tanning materials. Oleanolic acid has also been isolated from the bark. Analysis of the spent bark (residue left after extraction of tannins) gave the following values: moisture -13.46 , lignin -25.8 , pentosans - 15.6, furfural - 9.1, holocellulose 52.19 , and ash $-5.97 \%$. Resin and oil - on tapping the sal tree yields a oleoresin known as Sal Dammar or Bengal Dammar. Annual yield is 4-5 kg. of resin per tree. Resin is rough, stalactitic, brittle pieces, 16 - 24cu.mm in size, pale creamy yellow in colour, nearly opaque and having a faint resinuous balsamic odour. It has following constants: sp.gr. $-0.94-0.96$, sap. val. $-35-37$, acid val. - 22 -24. Sal resin on dry distillation yields an essential oil, known as Chua oil, and depending upon the sources of samples of resin the yield of oil has been recorded to vary from 41 to 68 percent. The oil is light brownish in colour and has agreeable incense like odour. The oil has following constants: sp.gr. 0.9420, acid val. 4.42, sap.val. - 15.72; and sap. val. After acetylation - 39.49. It consists of 96.0 percent neutral and 3 and 1 percent phenolic and acidic fractions respectively. Analysis of oil gave: homocatechol monomethyl ether - 0.46, 4-oxy- 3methoxy-ethyl benezene - 0.39, 4-oxy- 3methoxy-1-propylbenezene 0.53 , homocatechol dimethyl ether - 4.78, an unidentified phenol 2.42, 3- methoxy-4ethoxy-1-methyllbenezene 9.38, 3, 4-dimethoxy-1-propylbenezene - 15.88, oxygenated aromatic compounds - 40.25, and hydrocarbons (azualenes) - $25.91 \%$. It is used in medicine as an antiseptic for skin diseases and for ear troubles.

$\underline{\text { Seed and seed oil - an analysis of dried sal seed }}$ meal gave following values: moisture - 5.23, protein -6.16 , ether -16.77 , crude fibre -4.81 , $\mathrm{N}$-free extr. -63.25 , calcium -0.18 , total ash 3.78, and acid insoluble ash - 0.95\%. [ Nayak.et.al.,Indian vet J. 1967, 44,706; Panda, Farm, J. 1966-67,8(7),9].Seeds yield $19-20$ percent of fatty oil (sal butter) which is contained in cotyledons. The oil is greenish white to whitish in colour and has following constants: sp.gr. 0.96, m.p. -37 , titre -48 , acid val. -6 , sap. val. 186. The fatty acid composition of the oil is as follows: palmitic -8.3 , stearic -34.7 , arachidic 12.3, oleic - 41.9, and linoleic - 2.8\%. [ Sen, Bull. Dep. Developm.(Ind), Orrisa, No 2, 1940;Chem Abstr., 1942,36,4727;Indian oilseeds J. 1964,8,198.]

\section{Bibliography}

1. Amarsingh - Namalinganusasana (Amarkosa) with comm. by Bhanuji Dixit, edited by Pt. Sivanand, 6th edi., Nirnay Sagar Press, Bombay, 1944.

2. Anonymous : Economic Botany, 24, 247, 1970 in Glossary of Indian

3. Medicinal Plants with Active Principles Part I, 1992.

4. Anonymous: Indian J. Exp. Biol., 9, 91, 1971.

5. Anonymous Indian Journal of Exp. Biol. 12, 512, 1974 in Glossary of Indian Medicinal Plants with Active Principles, Part I, 1992.

6. Arunadatta - Sarvang Sundara on Astangahradaya, edited by H.P. Vaidya, 7th edition, Chaukhambha Orientalia, Varanasi, 1982.

7. Aselkar L. V., Vakar K. K., Chakri O. J. : Glossary of Indian Medicinal Plants with Active Principles (second supplement), Part I. (1965-1981), 141, 1992.

8. PSAF. Pharmacopoeial Standards for Ayurvedic Formulations. Central Council for Research in Ayurveda and Siddhha. Ministry of Health and Family Welfare, Govt of India, New Delhi. (1987).

9. Trease, G. E. and Evan, W. C. Pharmacognosy. $12^{\text {th }}$ edition, English Language Book Society, Balliere, Tindall. (1983).

10. WHO. Quality Control Methods for Medicinal Plant Materials. World Health Organisation, Geneva. (1998). 


\section{JMSCR Vol||05||Issue||09||Page 28021-28029||September}

11. Chase, C.R. and Pratt, F.J. Fluorescence of powered vegetable drugs with particular reference to development of a system of identification J. Am. Pharm. Assoc. (38) 324-331(1949).

12. Kokaski, J, Kokoski, R and Sima, F.J. Fluorescence of powered vegetable drugs under ultra violet radiation. J. Am. Pharm. Assoc. 47(10) 715-717 (1958).

13. Bhavamishra: Bhavaprakasa part I and II with vidyotini commentary.

14. Bhela Samhita; edited by Girirajadayalu Shukla.

15. Chakrapanidatta: Chakradatta with Bhavarthasandhipini commentary.

16. Chakravarthy C: The treatment and wound and abscess in the Sutrasthana of Sushruta Samhita.

17. Capbell D. F. and Anderson R.: Muir's text book of pathology ELBS ad Edward Arnold ltd.

18. Dhyani S.C. - Rasapancaka (Ayurvedic Principles of Drug action) $1^{\text {st }}$ edition, Krishnadas Academy, Varanasi, 1994.

19. Dietrich Brandis - Indian trees, 1906.

20. Duthie J. F., Flora of Upper Gangetic Plain - Vol. II, 192, 1903

21. Govind Das: Bhaishajyaratnavali with Vidyotini Commentary of Ambikadatta shastry.

22. Irvine W. T: Scientific basis of surgery.

23. Jain P. C. \& Khanna H. N.: pathogenesis of disease.

24. Jones Watson: Fractures and Joint Injury vol.I

25. Kent H. Thomas, NoelHart Micheal \& ShiresK. Thomas: Introduction of human disease.

26. Khory \&Katrek: Materia medica of India $\&$ their therapeutics.

27. Kirtikar K.R. and Basu B.D. 1935 Indian Medicinal plants, 2nd edition, Vol. I, Lalit Mohan Basu, Allahabad, India.
28. Madhavakara: Madhava Nidana with madhukosha commentary of Vijayaraksita ad Srikanthadatta and Vidyotini commentory of sudarsana Shastry.

29. Sharma P. V.: Dravyaguna Vigyan Vol. I \& II, Chaukhamba Bharati Academy, varanasi, 2001.

30. Sharma P. V.: Dravyaguna Vijnana parts I \& II. 